Available online at website : http://e-journal.adpgmiindonesia.com/index.php/jmie JMIE: Journal of Madrasah Ibtidaiyah Education, 3(2), 2019, 203-218

\title{
KELAYAKAN MODUL PEMBELAJARAN IPA TERINTEGRASI NILAI AGAMA UNTUK MENGEMBANGKAN KARAKTER RASA INGIN TAHU
}

\author{
Dita Hildayatni ${ }^{1}$, Retno Triwoelandari², Hilman Hakiem ${ }^{3}$ \\ Universitas Ibn Khaldun Bogor \\ Email: ditahildayatni@gmail.com¹, retnotriwoelandari@fai.uika-bogor.ac.id², hilman@uika-bogor.ac.id ${ }^{3}$ \\ Naskah diterima : 10 Juli 2019, direvisi : 20 September 2019, disetujui : 25 September 2019
}

\begin{abstract}
The learning module used so far has not adjusted to the needs of students. The purpose of this study is to determine the feasibility of integrated science learning modules of religious values to develop students' curiosity character. This study uses the Research and Development (R \& D) method through three steps, namely preliminary study, product development, and model testing. The research instruments were in the form of questionnaires and observation sheets. The results of this study are obtained by the percentage of the feasibility of material experts amounting to $81.73 \%$ with a very valid category, linguists show a figure of $75 \%$ with a valid category, design experts show a number of $70.83 \%$ with valid categories, and field test results of $85.71 \%$. It can be concluded that an integrated science learning module worthy of religious value is used to develop the character of students' curiosity.
\end{abstract}

Keywords: Learning Module, Integrated Value Of Region, Curiosity Character.

Pengutipan: . Dita Hildayatni, dkk. (2019). Kelayakan Modul Pembelajaran IPA Terintegrasi Nilai Agama Untuk. Mengembangkan Karakter Rasa Ingin Tabu. JMIE: Journal of Madrasah Ibtidaiyah Education,3(2), 2019, 203-218. jmie.v3i2.107.

Permalink/DOI: http://dx.doi.org/10.32934/jmie.v3i2.107 


\section{PENDAHULUAN}

Ilmu Pengetahuan Alam merupakan salah satu ilmu yang mempelajari suatu konsep yang berkaitan dengan kehidupan sehari-hari. Melalui pembelajaran IPA, dapat memunculkan tingkat keingintahuan siswa terhadap sesuatu dengan tujuan agar mampu menghadapi dan menyelesaikan berbagai masalah yang ditemuinya. Maka dari itu kegiatan pembelajaran harus dirancang dengan menarik dan mampu menciptakan suasana pembelajaran yang dapat merangsang rasa ingin tahu siswa dengan memposisikan guru sebagai fasilitator saja sehingga siswa yang lebih dituntut untuk aktif selama kegiatan pembelajaran berlangsung. Artinya dalam proses pembelajarannya IPA tidak hanya disampaikan melalui teori saja akan tetapi melibatkan siswa untuk aktif, seperti aktif dalam kegiatan mengamati, mengidentifikasi, diskusi, tanya jawab dan mencari tahu. Kegiatan tersebut bertujuan agar siswa mampu dalam mengatasi dan mencari solusi dari setiap masalah yang ditemuinya, serta rasa penasarannya pun akan selalu berkembang. Menurut Suyadi (2015 : 9) keingintahuan yang ada dalam diri setiap individu adalah cara berpikir, berperilaku, dan menyikapi segala sesuatu yang mencerminkan rasa penasaran terhadap segala aspek baik yang dilihat, didengar serta dipelajari secara lebih mendalam untuk menemukan titik temu atau jawaban dari rasa penasarannya tersebut. Maka dapat disimpulkan rasa ingin tahu sangat penting dimiliki oleh siswa agar pengetahuannya selalu berkembang dan mampu untuk berpikir lebih maju agar dapat menghadapi segala tantangan dalam setiap perkembangan zaman.

Menurut Mulyasa (2016 : 6) kurikulum 2013 merupakan kurikulum yang lebih difokuskan untuk membentuk akhlak peserta didik. Pada kurikulum ini ada tiga aspek yang sangat diperhatikan yaitu aspek kognitif, afektif, dan psikomotorik. Konsep pembelajarannya yaitu menggunakan konsep pembelajaran tematik, jadi memuat beberapa mata pelajaran menjadi satu tema. Dalam satu tema terdapat beberapa sub tema yang terdiri dari enam pembelajaran. Sehingga buku pegangan yang digunakan oleh guru maupun siswa sudah dirancang menjadi satu tema yang sudah terintegrasi dengan mata pelajaran yang lain. Pembentukan karakter dalam kurikulum ini biasanya terbentuk dari materi-materi yang dipelajari.

Namun pada kenyataanya buku yang selama ini digunakan oleh siswa kelas 5 dibeberapa SD/MI yang ada di Kota Bogor belum sepenuhnya menyeseuaikan pada kebutuhan siswa. Buku yang digunakan memang sudah tertulis karakter yang akan dikembangkan, akan tetapi ketika diimplementasikan ke dalam kegiatan pembelajaran belum sesuai dengan kondisi siswa. Tidak hanya itu penyajian dalam buku juga kurang menarik. Pada satu sisi menurut Wena (2016 : 229) keberadaan buku teks dengan kualitas yang baik masih sangat kurang. Hal ini terlihat dari buku-buku yang digunakan lebih menekankan pada misi 
pengetahuan saja dan kurang menyesuaikan dengan kebutuhan siswa. Akibatnya kurang adanya pemahaman siswa yang lebih mendalam terhadap buku yang dibacanya serta tidak jarang buku bisa menjadi penyebab munculnya rasa bosan pada siswa apabila buku dikemas kurang menarik. Tidak hanya itu dalam pelajaran IPA buku yang digunakan masih secara umum saja belum adanya pengintegrasian dengan nilai-nilai Islam dan materi yang disampaikan hanya dengan teori-teori ilmiah saja, padahal sejatinya keberadaan IPA sangat berkaitan dengan nilai-nilai agama. Dalam penelitian yang dilakukan oleh Sri Latifah mengenai pengembangan modul IPA yang terintegrasi dengan ayat-ayat Al-Qur'an dalam proses pembelajarannya seorang guru harus mampu memberikan pemahaman kepada siswa bahwa alam semesta ini tidak terlepas begitu saja dari kekuasaan Allah SW'T selain untuk memberikan pemahaman mengenai keterkaitan antara ilmu sains dengan ilmu agama hal ini dapat memperkuat keyakinan siswa kepada Allah SWT serta mampu untuk menumbuhkan karakter siswa yang religius (Latifah, 2015 : 157). Selama ini guru hanya cukup mengajar saja, belum sepenuhnya dapat mengembangkan bahan ajar yang kreatif dan inovatif. Teori yang disampaikan hanya sekedar teori-teori umum, belum adanya pengintegrasian antara ilmu alam dengan nilai-nilai Islam karena selama ini antara ilmu alam dengan ilmu agama dipelajari secara terpisah. Sehingga siswa kurang memaknai bahwa sesungguhnya segala yang terjadi di alam semesta ini sudah dijelaskan dalam Al-Qur'an.

Menanggapi masalah-masalah yang ditemukan, keberadaan bahan ajar sangat penting. Tidak hanya sekedar dibuat, akan tetapi bahan ajar harus dapat menyesuaikan kebutuhan siswa. Artinya bahan ajar dapat dikembangkan sendiri oleh guru karena guru lebih mengetahui kondisi serta karakteristik siswanya. Bahan ajar yang dapat dikembangkan oleh guru salah satunya yaitu dapat berupa modul pembelajaran. Menurut Prastowo (2014 : 106) modul pembelajaran diartikan sebagai bahan ajar yang dirancang sesuai dengan tingkat karakteristik siswa baik dari segi bahasa maupun tampilan modul agar mudah dipahami oleh siswa dengan tujuan modul bisa digunakan untuk belajar sendiri. Dapat disimpulkan bahwa modul pembelajaran harus menyesuaikan dengan karakterisitik dan kebutuhan siswa agar siswa lebih mudah dalam memahami isi dan materi pada modul tersebut.

Adapun dalam penelitian yang dilakukan oleh Achmad Subekti Trimantoto mengenai pengembangan modul pembelajaran tematik bahwa materi yang disampaikan oleh guru maupun yang tertulis di buku masih sulit dipahami oleh siswa karena buku yang disusun kurang melihat pada kebutuhan siswa di lapangan sehingga mengakibatkan siswa mengalami kebingungan dalam menerima materi dan tidak jarang proses pembelajaran menjadi terhambat (Trimantoto, 2016 : 214-215). Dapat disimpulkan bahawa buku-buku yang selama ini digunakan kurang melihat pada kebutuhan dan karakterisitik siswa. Pada saat siswa mengalami 
kesulitan dalam memahami materi tidak adanya keberanian siswa untuk bertanya atau menjawab pertanyaan dari guru sehingga masih kurangnya karakter rasa ingin tahu siswa pada saat proses pembelajaran berlangsung. Dalam penelitian yang dilakukan oleh Steven Raharja mengenai mengukur rasa ingin tahu siswa bahwa pendidikan yang berhasil berkaitan erat dengan banyak faktor, seperti peran guru, peserta didik, dan proses pembelajaran. Peserta didik dalam proses pembelajara dipengaruhi oleh kesungguhan peserta didik dalam belajar. Kesungguhan tersebut tergantung dari keinginan yang timbul dari dalam dirinya. Keinginan itulah yang dinamakan dengan rasa ingin tahu. Rasa ingin tahu yang tinggi dapat memberikan dampak proses kegiatan pembelajaran lebih baik. Oleh karena itu, rasa ingin tahu adalah suatu hal yang penting dalam proses pembelajaran (Raharja, 2018 : 153). Maka dari itu rasa ingin tahu sangat penting untuk dikembangkan. Dengan memiliki rasa ingin tahu yang tinggi siswa dapat menambah pengetahuannya, tidak hanya itu sikap ilmiah dan keterampilan siswa juga dapat terbentuk melalui kegiatan-kegiatan seperti melakukan pengematan, identifikasi dan mencari tahu agar siswa dapat mampu menyelesaikan setiap masalah yang ditemuinya.

Dari permasalahan yang ditemukan, peneliti mengembangkan sebuah bahan ajar berupa modul pembelajaran IPA terintegrasi nilai agama untuk mengembangkan karakter rasa ingin tahu. Modul pembelajaran ini disusun dengan menyesuaikan karakteristik siswa. Tujuan dari penelitian ini adalah untuk mengetahui kelayakan modul pembelajaran IPA terintegrasi nilai agama untuk mengembangkan karakter rasa ingin tahu. Penelitian ini fokus mengembangkan modul pembelajaran IPA dengan tema "Lingkungan Sahabat Kita" sub tema "Usaha Pelestarian Lingkungan" untuk mengembangkan karakter rasa ingin tahu siswa kelas 5 $\mathrm{SD} / \mathrm{MI}$.

\section{METODE PENELITIAN}

Metode yang digunakan dalam penelitian ini yaitu Research and Development (R\&D) atau penelitian dan pengembangan yang telah disederhanakan oleh Sukmadinata (2011 : 184-187) yang terdiri dari tiga langkah yaitu studi pendahuluan, pengembangan produk, dan uji model. Adapun langkah-langkah tersebut digambarkan pada Gambar 1. di bawah ini : 

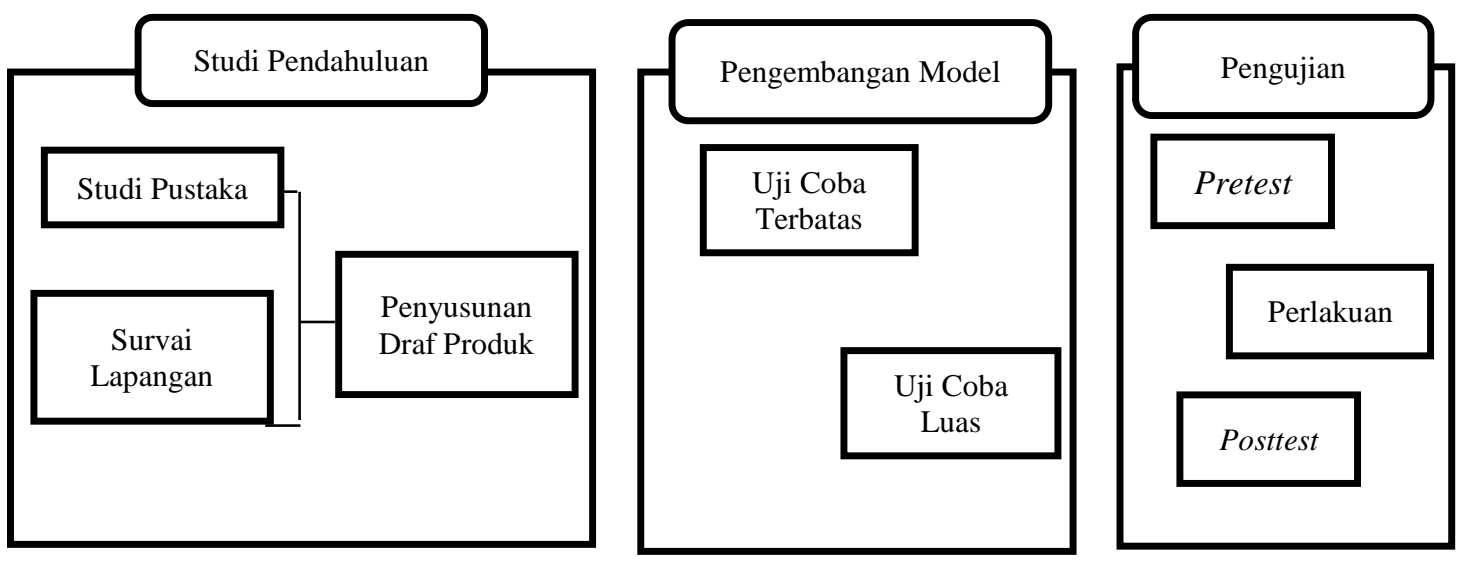

Gambar 1. Langkah-Langkah R\&D Dimodifikasi

Studi pendahuluan terdiri dari studi pustaka yaitu mengkaji konsep maupun teori yang berkaitan dengan produk yang akan dikembangkan. Selanjutnya melakukan kegiatan untuk mengumpulkan data yang berkenaan dengan perencanaan dan pelaksanaan pembelajaran IPA terutama dalam menanamkan nilai-nilai Islam pada pembelajaran IPA kegiatan ini disebut dengan survey lapangan. Kemudian peneliti menyusunan draf produk. Dalam penelitian ini produk yang dikembangkan yaitu berupa modul pembelajaran. Modul yang akan disusun adalah modul pembelajaran IPA yang diintegrasikan dengan nilai agama untuk mengembangkan karakter rasa ingin tahu siswa. Setelah melakukan studi pendahuluan langkah selanjutnya yaitu pengembangan model dimana modul yang telah dibuat kemudian di uji coba. Langkah terakhir yaitu tahap pengujian yang dilakukan dengan metode eksperimental yaitu digunakan dua kelompok sampel yang terdiri dari kelas eksperimen dan kelas kontrol.

Sampel yang digunakan yaitu siswa kelas 5 SDN Kebon Pedes 7 dengan jumlah 56 siswa. dari jumlah tersebut peneliti membagi menjadi dua kelas yaitu kelas eksperimen dan kelas kontrol. Pada kelas eksperimen terdiri dari 28 siswa dan kelas kontrol terdiri dari 28 siswa. Teknik pengumpulan data yang dilakukan adalah dengan menggunakan lembar angket yang diberikan kepada tim ahli untuk menilai produk modul pembelajaran ini dan lembar observasi untuk mengamati karakter rasa ingin tahu siswa. Tim ahli terdiri dari tim ahli materi, ahli bahasa, dan ahli desain serta hasil penilaian modul dengan memberikan lembar angket respon siswa. Lembar angket ini berisi kriteria kelayakan sesuai yang dikeluarkan oleh Badan Standar Nasional Pendidikan (BSNP).

Selanjutnya data yang diperoleh dari hasil angket kemudian dianalisis dengan menggunakan rumus sebagai berikut : 


$$
\text { Persentase }=\frac{\text { Perolehan skor }}{\text { Skor maksimal }} \times 100
$$

Setelah didapatkan hasil dari perhitungan tersebut tahap selanjutnya menurut Riduwan (2012 : 15) yaitu melihat kualifikasi nilai dari skala tingkat pencapaiannya seperti tabel di bawah ini:

Tabel 1. Kriteria Interpretasi Skor

\begin{tabular}{|lcc|}
\hline \multicolumn{3}{|c|}{ Kriteria Interpretasi Skor } \\
\hline Persentase & Kualifikasi & Kriteria Kelayakan \\
\hline $81 \%-100 \%$ & Sangat Valid & Tidak Revisi \\
\hline $61 \%-80 \%$ & Valid & Tidak Revisi \\
\hline $41 \%-60 \%$ & Cukup Valid & Perlu Revisi \\
\hline $21 \%-40 \%$ & Kurang Valid & Revisi \\
\hline $0 \%-20 \%$ & Sangat Kurang Valid & Revisi Total \\
\hline
\end{tabular}

Adapun lembar observasi digunakan untuk mengamati karakter rasa ingin tahu siswa. Lembar observasi ini terdiri dari 15 indikator pencapaian karakter rasa ingin tahu siswa. Selanjutnya data dianalisis dengan menggunakan SPSS-20 For Windows. Data yang dianalisis merupakan hasil pengamatan karakter rasa ingin tahu siswa yang dilakukan pada tahap uji validasi dengan menggunakan uji t yang digunakan adalah paired sample t-test untuk menguji perbandingan rata-rata berpasangan yaitu pretest dan posttest serta independent sample t-test untuk menguji perbandingan rata-rata hasil posttest antara kelas eksperimen dan kelas kontrol.

\section{HASIL DAN PEMBAHASAN}

\section{HASIL PENELITIAN}

Berdasarkan hasil penelitian modul pembelajaran dinilai oleh tim ahli yang sesuai dengan bidangnya masing-masing. Penilaian tersebut dilakukan oleh ahli materi, ahli bahasa, dan ahli desain dengan tujuan untuk mengetahui tingkat kelayakan dari modul pembelajaran. akan tetapi meskipun modul pembelajaran sudah dinyatakan valid, tim ahli tetap memberikan komentar dan saran agar modul pembelajaran menjadi lebih baik. Berikut adalah hasil dari rekapitulasi nilai kelayakan modul pembelajaran :

Tabel 2. Hasil Penilaian Modul Pembelajaran

\begin{tabular}{|lcc|}
\hline & Hasil Penilaian Modul Pembelajaran \\
\hline Validator & Persentase & Keterangan \\
\hline Ahli Materi & $81,73 \%$ & Sangat Valid \\
\hline Ahli Bahasa & $75 \%$ & Valid \\
\hline Ahli Desain & $70,83 \%$ & Valid \\
\hline
\end{tabular}


Berdasarkan Tabel 2. Penilaian dari ahli materi memperoleh persentase tingkat kelayakan sebesar 81,73\% dengan kategori sangat valid. Adapun komentar dan saran yang diberikan oleh ahli materi yaitu perbaikan pada daftar pustaka. Peneliti melakukan perbaikan pada bagian daftar pustaka tepatnya pada bagian posisi yang salah dalam penulisan seperti pada Gambar 2. di bawah ini :
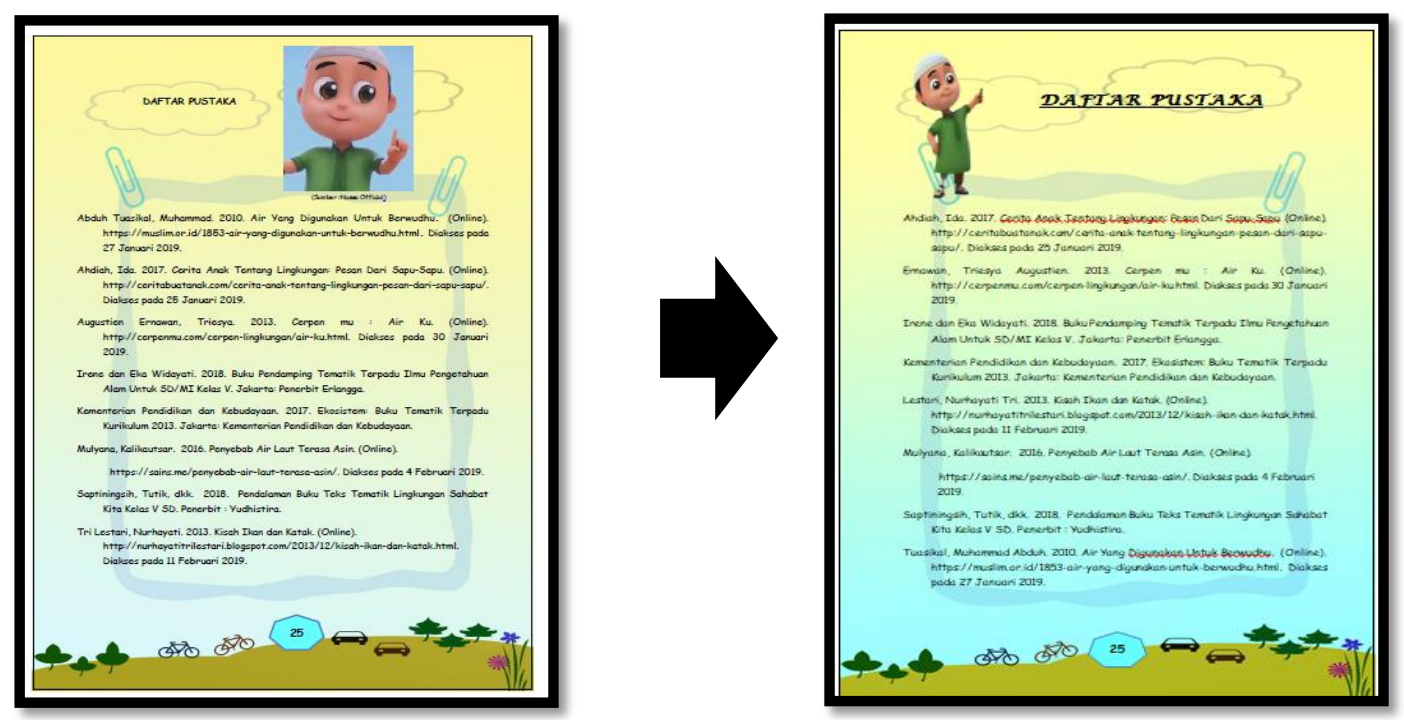

Gambar 2. Daftar Pustaka Sebelum dan Setelah Direvisi

Penulisan yang diperbaiki dalam daftar pustaka diantaranya posisi penulisan nama penerbit dari sumber yang peneliti gunakan yaitu nama penerbit "Abduh Tuasikal, Muhammad dirubah menjadi Tuasikal, Muhammad Abduh", selanjutnya "Agustien Ernawan, Triesya dirubah menjadi Ernawan, Triesya Agustien”, dan perbaikan penulisan pada daftar pustaka yang terakhir yaitu "Tri Lestari, Nurhayati dirubah menjadi "Lestari, Nurhayati Tri” itulah beberapa perbaikan penulisa pada daftar pustaka.

Penilaian ahli bahasa diperoleh tingkat kelayakan sebesar 75\% dengan kategori valid. Adapun komentar dan saran yang diberikan oleh ahli bahasa yaitu meperbaiki kalimat pada tujuan pembelajaran "Melalui kegiatan berdiskusi siswa mampu menyebutkan syarat-syarat yang mempengaruhi kualitas air dengan benar" menjadi "Melalui kegiatan diskusi siswa dapat menyebutkan 3 syarat yang mempengaruhi kualitas air dengan benar" serta adanya perbaikan pada kegiatan ayo mengaji dimana peneliti menambahkan kalimat pengantar pada ayat $\mathrm{Al}-$ Qur'an dan Hadist serta kaitannya dengan materi seperti pada Gambar 3. dan 4. di bawah ini : 

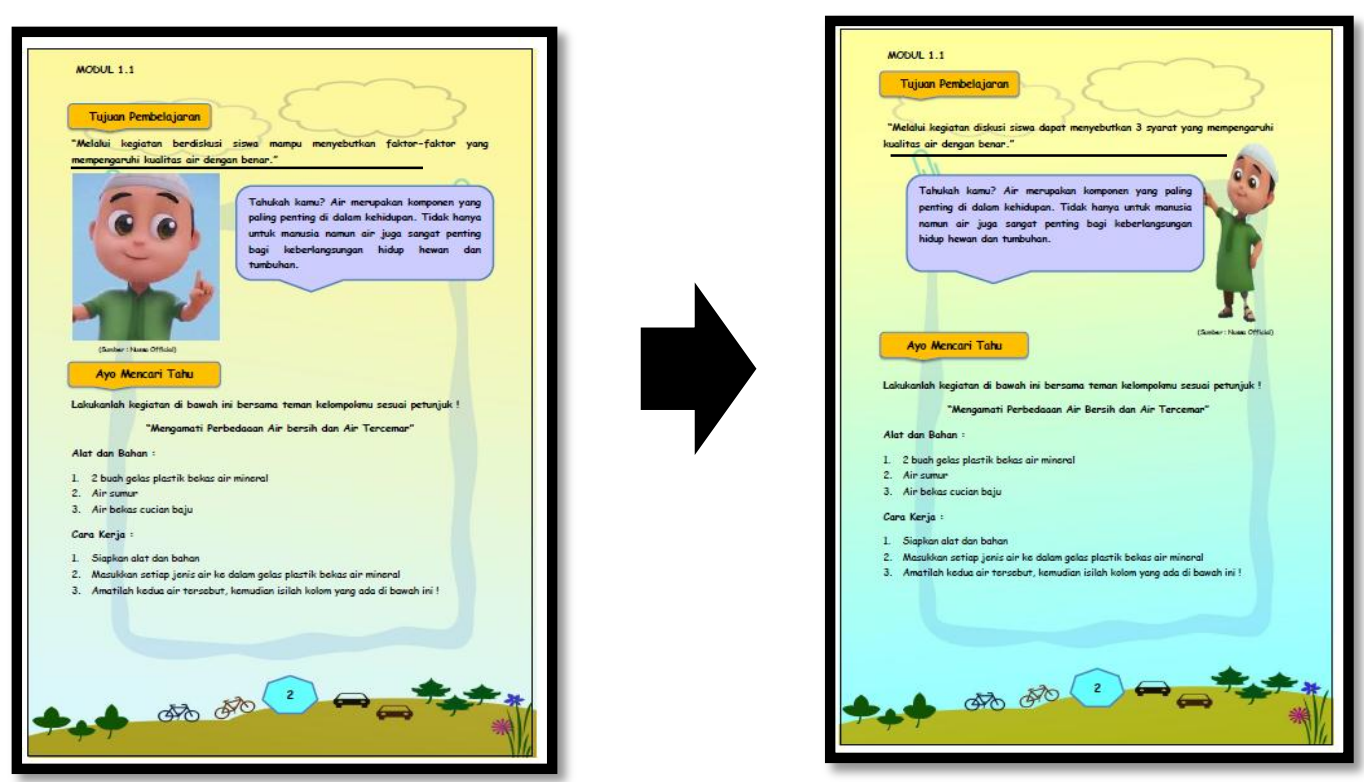

Gambar 3. Tujuan Pembelajaran Sebelum dan Setelah Direvisi
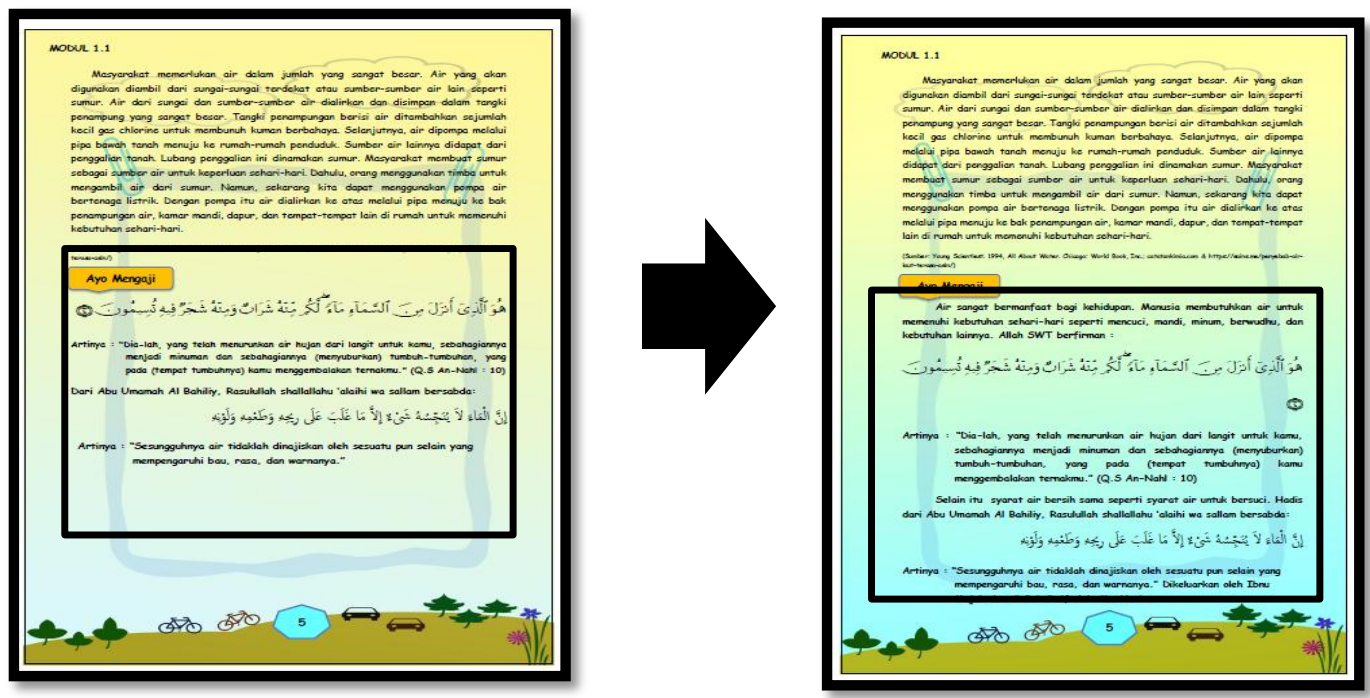

Gambar 4. Kegiatan Ayo Mengaji Sebelum dan Setelah Direvisi 
Pada gambar 4. Kegiatan ayo mengaji diperbaiki karena tidak ada kalimat pengantar dalam penyampaian ayat Al-Qur'an dan Hadits sehingga ditambahkan kalimat pengantar yaitu "Air sangat bermanfaat bagi kehidupan. Manusia membutuhkan air untuk memenuhi kebutuhan sehari-hari seperti mencuci, mandi, minum, berwudhu dan kebutuhan lainnya." dan kalimat "Selain itu syarat air bersih sama seperti syarat untuk bersuci" setelah ditambahkan kalimat pengantar lalu dijelaskanlah ayat Al-Qur'an dan Hadits yang berkaitan dengan materi.

Selanjutnya penilaian ahli desain diperoleh tingkat kelayakan sebesar 70,83\% dengan kategori valid, komentar dan saran yang diberikan oleh ahli desain yaitu warna background pada modul terlalu terang sehingga peneliti memperbaiki warna background dengan sedikit lebih gelap seperti pada Gambar 5 di bawah ini :
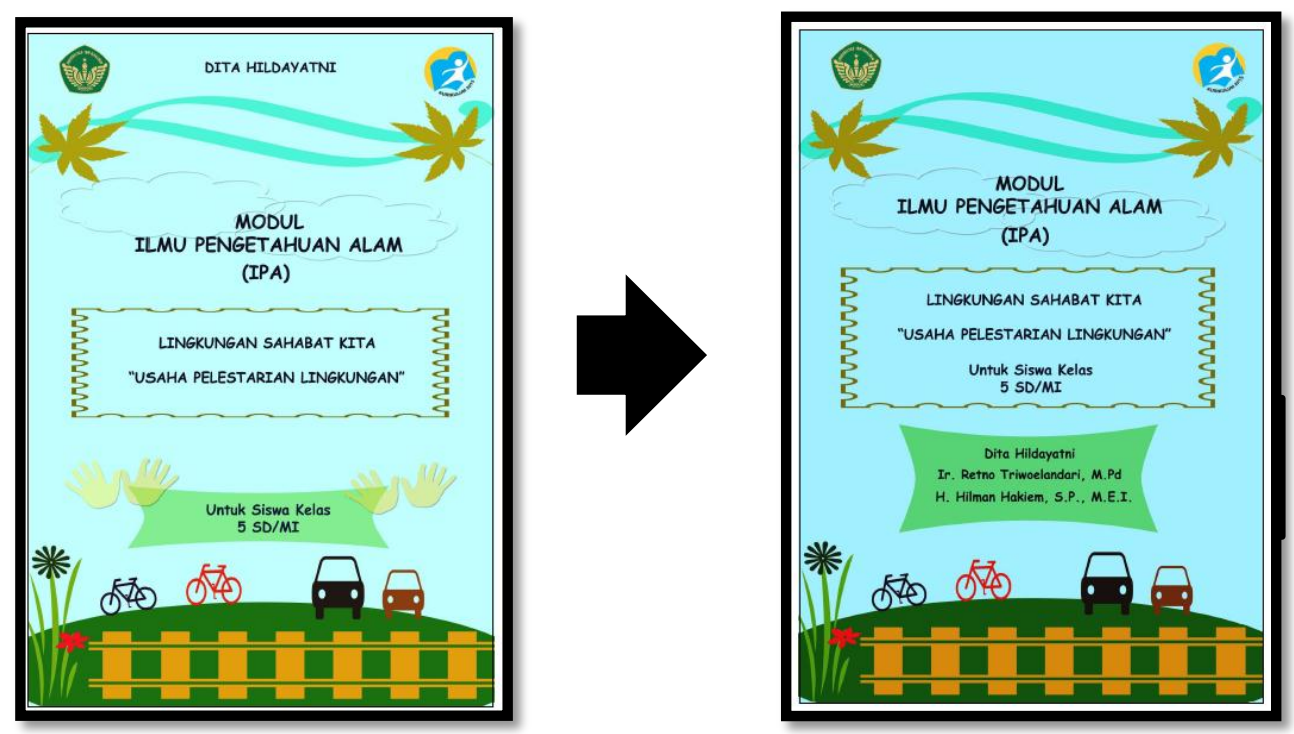

Gambar 5. Background Cover Sebelum dan Setelah Direvisi

Setelah dilakukan penilaian oleh tim ahli selanjutnya modul pembelajaran dinilai oleh siswa kelas 5 pada tahap uji validasi untuk mengetahui respon siswa mengenai modul pembelajaran yang telah digunakan dengan membagikan lembar yang berisi beberapa pernyataan. Lembar tersebut terdiri dari aspek ketertarikan, aspek materi dan aspek bahasa. Adapun hasil respon siswa dapat dilihat pada Tabel 3. di bawah ini : 
Tabel 3. Hasil Rekapitulasi Angket Respon Siswa

\begin{tabular}{|c|c|c|}
\hline \multicolumn{3}{|c|}{ Hasil Angket Respon Siswa } \\
\hline $\begin{array}{c}\text { Kriteria } \\
\text { Penilaian }\end{array}$ & Butir Penilaian & Skor \\
\hline \multirow{3}{*}{ Ketertarikan } & 1. Tampilan modul pembelajaran menarik & 96 \\
\hline & $\begin{array}{l}\text { 2. Modul pembelajaran ini dapat membangkitkan } \\
\text { semangat dalam belajar terutama dalam pelajaran } \\
\text { IPA }\end{array}$ & $\begin{array}{c}10 \\
3\end{array}$ \\
\hline & $\begin{array}{l}\text { 3. Dengan adanya modul pembelajaran kegiatan } \\
\text { pembelajaran menjadi tidak membosankan }\end{array}$ & 89 \\
\hline \multirow{7}{*}{ Materi } & $\begin{array}{l}\text { 4. Materi yang terdapat pada modul disajikan dengan } \\
\text { jelas dan mudah dipahami }\end{array}$ & $\begin{array}{c}10 \\
6\end{array}$ \\
\hline & 5. $\quad$ Petunjuk pada setiap bab ditulis dengan jelas & $\begin{array}{c}10 \\
0\end{array}$ \\
\hline & $\begin{array}{l}\text { 6. Gambar dan materi pada modul disajikan dengan } \\
\text { jelas }\end{array}$ & $\begin{array}{c}10 \\
4\end{array}$ \\
\hline & 7. Kegiatan percobaan dalam modul mudah dilakukan & $\begin{array}{c}10 \\
1\end{array}$ \\
\hline & $\begin{array}{l}\text { 8. Potongan ayat-ayat Al-Qur'an yang dicantumkan } \\
\text { untuk mengintegrasikan antara ilmu pengetahuan } \\
\text { umum dengan ilmu agama disajikan sesuai dengan } \\
\text { materi yang berkaitan }\end{array}$ & $\begin{array}{c}10 \\
2\end{array}$ \\
\hline & $\begin{array}{l}\text { 9. Modul pembelajaran ini mendorong saya untuk } \\
\text { dapat berdiskusi dengan baik bersama teman-teman } \\
\text { di kelas }\end{array}$ & 83 \\
\hline & $\begin{array}{l}\text { 10. Adanya soal latihan dan evalusai dapat mengetahui } \\
\text { seberapa jauh kemampuan pemahaman saya } \\
\text { terhadap materi }\end{array}$ & 93 \\
\hline \multirow{3}{*}{ Bahasa } & $\begin{array}{l}\text { 11. Kalimat yang disusun dalam modul pembelajaran } \\
\text { ini jelas dan mudah dipahami }\end{array}$ & 86 \\
\hline & 12. Bahasa yang digunakan sistematis & 87 \\
\hline & 13. Huruf yang digunakan mudah dibaca & 98 \\
\hline \multicolumn{2}{|r|}{ Perolehan Skor } & 1,248 \\
\hline \multicolumn{2}{|r|}{ Skor Maksimal } & 1,456 \\
\hline
\end{tabular}

Berdasarkan Tabel 3. di atas menunjukkan hasil dari angket respon siswa diperoleh skor 1,248 dari skor maksimal 1,456, kemudian hasil tersebut dihitung ke dalam bentuk persentase sehingga diperoleh hasil sebesar 85,71\% dengan kategori sangat valid. Artinya modul pembelajaran ini layak digunakan dan dapat mengembangkan karakter rasa ingin tahu siswa. 
Selanjutnya adapun hasil untuk mengetahui ada tidaknya peningkatan karakter rasa ingin tahu siswa. Sebelum menganalisis data maka dilakukan uji normalitas dan uji homogenitas terlebih dahulu. Hasil yang diperoleh yaitu data berdistribusi normal dan homogen. Selanjutnya data dianalisis dengan menggunakan uji t untuk mengetahui karakter rasa ingin tahu siswa melalui pretest dan posttest pada kelas eksperimen dan kelas kontrol yang dianalisis dengan menggunakan SPSS 20 For Windows. Berikut merupakan hasil rata-rata pretest dan posttest kelas eksperimen dan kelas kontrol dapat dilihat pada Tabel 4. berikut ini:

Tabel 4. Hasil Rata-Rata Pretest dan Posttest SDN Kebon Pedes 7

\begin{tabular}{|lcc|}
\hline \multicolumn{3}{|c|}{ Hasil Rata-Rata Pretest dan Posttest } \\
\hline Kelas & Pretest & Posttest \\
\hline Kelas Eksperimen & 23,0357 & 33,2857 \\
\hline Kelas Kontrol & 20,6786 & 26,8571 \\
\hline
\end{tabular}

Berdasarkan Tabel 4. diperoleh hasil rata-rata pretest kelas eksperimen sebesar 23,0357 dan posttest sebesar 33,2857. Pada kelas kontrol diperoleh hasil pretest sebesar 20,6786 dan posttest sebesar 26,8571. Hal ini menunjukkan adanya peningkatan karakter rasa ingin tahu siswa, karena terdapat perbedaan hasil rata-rata antara nilai pretest dengan nilai posttest. Namun hasil rata-rata lebih besar pada kelas eksperimen, karena kelas eksperimen merupakan kelas yang diberikan perlakuan dengan menggunakan modul pembelajaran IPA terintegrasi nilai agama. Adapun hasil nyata dari peningkatan karakter rasa ingin tahu dengan menggunakan modul pembelajaran tematik IPA terintegrasi nilai agama yang dapat diketahui melalui perhitungan dengan menggunakan SPSS sebagai berikut :

Tabel 5. Paired Samples T-Test SDN Kebon Pedes 7 Kelas Eksperimen

\begin{tabular}{|c|c|c|c|c|c|c|c|c|c|}
\hline & \multicolumn{5}{|c|}{ Paired Differences } & \multirow[t]{3}{*}{$\mathrm{T}$} & \multirow{3}{*}{ Df } & \multirow{3}{*}{$\begin{array}{l}\text { Sig. (2- } \\
\text { tailed) }\end{array}$} \\
\hline & & \multirow[t]{2}{*}{ Mean } & \multirow[t]{2}{*}{$\begin{array}{c}\text { Std. } \\
\text { Deviatio } \\
\mathrm{n}\end{array}$} & \multirow[t]{2}{*}{$\begin{array}{l}\text { Std. } \\
\text { Eror } \\
\text { Mean }\end{array}$} & \multicolumn{2}{|c|}{$\begin{array}{c}95 \% \text { Confidence } \\
\text { Interval of the } \\
\text { Difference }\end{array}$} & & & \\
\hline & & & & & Lower & Upper & & & \\
\hline $\begin{array}{c}\text { Pair } \\
1\end{array}$ & $\begin{array}{l}\text { Pretest - } \\
\text { Posttest }\end{array}$ & -10.25000 & 3.28436 & 62069 & -11.52354 & -8.97646 & -16.514 & 27 & .000 \\
\hline
\end{tabular}

Pada Tabel 5. terlihat adanya perbedaan rata-rata antara nilai pretest dengan nilai posttest kelas eksperimen yaitu sebesar -10,25000. Tanda minus (-) berarti menunjukkan bahwa hasil posttest lebih besar dari hasil pretest. Data frekuensi (df) diperoleh dari rumus n-1 yaitu banyaknya jumlah responden maka diperoleh df sebesar 28-1 yaitu 27. Hasil perhitungan nilai "t" adalah 
sebesar 16,514 dengan p-value 0,000 sig (2-tailed) yang artinya kurang dari 0, 05. Hal ini berarti $\mathrm{H}_{\mathrm{o}}$ ditolak dan $\mathrm{H}_{\mathrm{a}}$ diterima.

Tabel 6. Paired Samples T-Test SDN Kebon Pedes 7 Kelas Kontrol

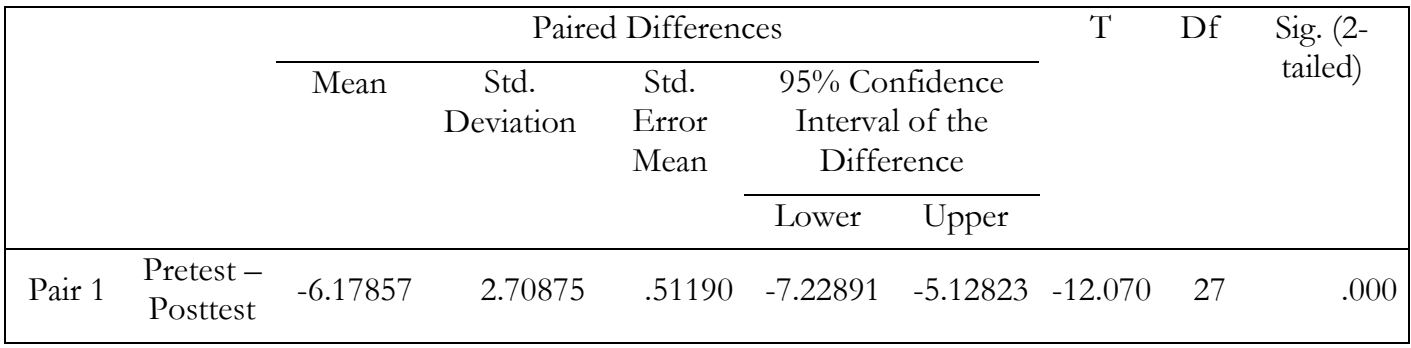

Pada Tabel 6. terlihat adanya perbedaan rata-rata antara nilai pretest dengan nilai posttestkelas eksperimen yaitu sebesar -6,17857. Tanda minus (-) berarti menunjukkan bahwa hasil posttest lebih besar dari hasil pretest. Data frekuensi (df) diperoleh dari rumus n-1 yaitu banyaknya jumlah responden maka diperoleh df sebesar 28-1 yaitu 27. Hasil perhitungan nilai “t” adalah sebesar 12,070 dengan p-value 0,000 sig (2-tailed) yang artinya kurang dari 0, 05. Hal ini berarti $\mathrm{H}_{\mathrm{o}}$ ditolak dan $\mathrm{H}_{\mathrm{a}}$ diterima.

Berdasarkan penilaian dari hasil pretest dan posttest pada kelas kontrol dan kelas eksperimen dengan penilaian paired sample t-test maka dapat dilakukan analisis dengan menggunakan independent sample t-test untuk mengetahui hasil perhitungan posttest pada kelas kontrol dan kelas eksperimen sebagai berikut :

Tabel 6. Independent Samples T-Test Kelas Eksperimen dan Kelas Kontrol

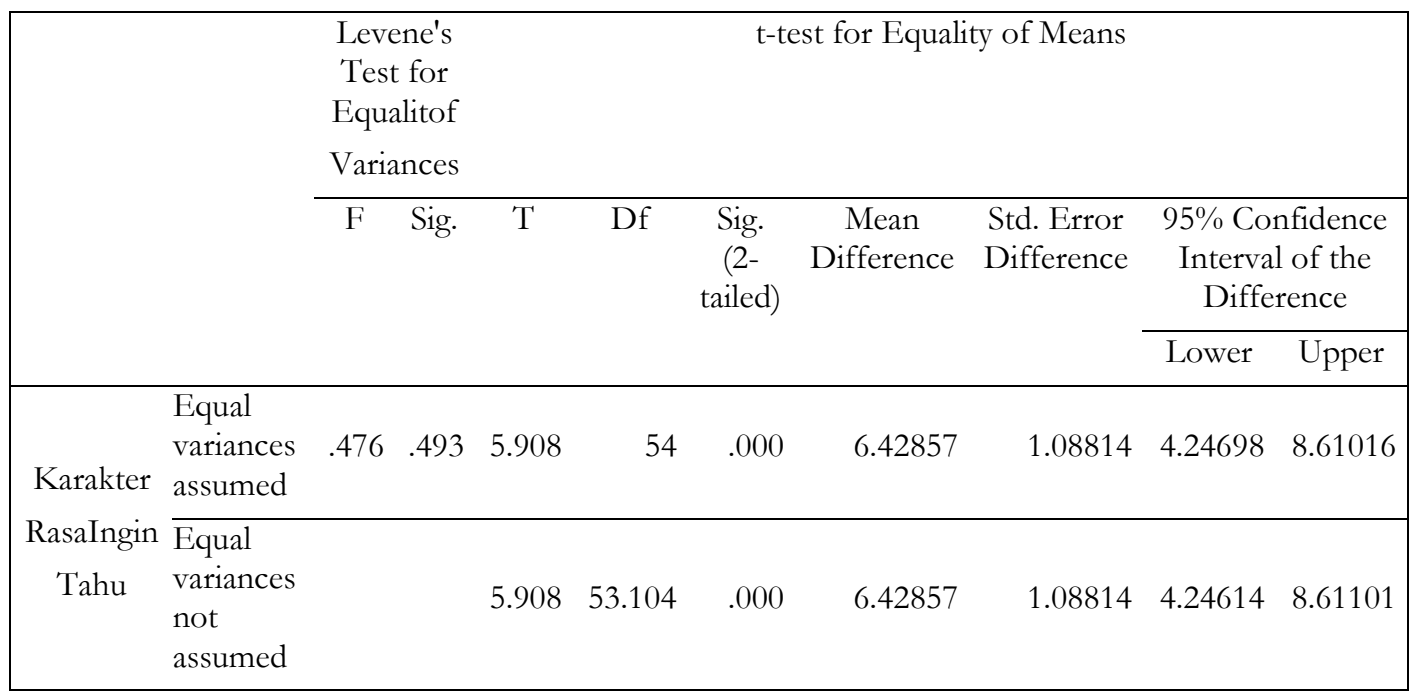


Pada Tabel 6. menunjukkan data independent sample t-test yaitu diperoleh rata-rata kelas eksperimen dan kelas kontrol sebesar 6,42857 dengan sig (2-tailed) sebesar 0,000. Dari hasil tersebut maka $\mathrm{H}_{\mathrm{a}}$ diterima dan terdapat perbedaan yang signifikan terhadap penggunaan modul pembelajaran ini. Maka modul pembelajaran tematik IPA terintegrasi nilai agama ini dapat mengembangkan karakter rasa ingin tahu pada siswa.

\section{PEMBAHASAN}

Sesuai dengan hasil yang diperoleh modul pembelajaran ini layak digunakan. Modul pembelajaran ini telah dilakukan penilaian oleh tim ahli yang terdiri dari ahli materi, ahli bahasa, dan ahli desain. Kriteria penilaian merujuk pada kriteria penilaian yang dikeluarkan oleh Badan Standar Nasional Indonesia (BSNP). Penilaian ahli materi dilakukan oleh dosen Program Studi Pendidikan Guru Madrsah Ibtidaiyah yaitu ibu Retno Triwoelandari, Ir., M.Pd. Penilaian dalam aspek materi ini terdiri dari segi kelayakan isi dan kelayakan penyajian. Hasil yang diperoleh yaitu sebesar 81,73\% dengan kategori sangat valid. Selain memberikan penilaian adapun komentar dan saran guna memperbaiki modul pembelajaran agar menjadi lebih baik. Komentar dan saran yang diberikan yaitu peneliti harus melakukan perbaikan pada bagian daftar pustaka yang masih salah dalam penulisannya. Modul pembelajaran layak dalam aspek materi karena penyajian modul pembelajaran tidak hanya sekedar menyajikan materi secara umum saja akan tetapi juga terdapat potongan ayat Al-Qur'an yang disisipkan pada modul ini, hal ini bertujuan agar dapat menambah keyakinan siswa bahwa Ilmu Pengetahuan Alam berkaitan dengan nilai-nilai Islam sebagaimana yang dijelaskan oleh Mulyadhi dalam Faiza (2017 : 103) bahwa mengintegrasikan pembelajaran tentang alam dengan nilai agama dapat menambah keyakinan siswa dimana segala yang ada di alam semesta ini adalah cipataan Allah SWT dan segala sesuatunya sudah dijelaskan dalam Al-Qur'an. Selain itu dalam modul pembelajaran ini terdapat petunjuk untuk membimbing siswa melakukan kegiatan pembelajaran, terdapat lembar kerja siswa yang bertujuan agar memunculkan tingkat rasa ingin tahu siswa, lembar evaluasi, kunci jawaban, serta cerita hikmah yang mengandung nilai-nilai Islam. Hal ini sesuai dengan pernyataan Sudjana, dkk (2013 : 134) bahwa modul pembelajaran harus memiliki unsur-unsur yang terdiri dari panduan kegiatan untuk guru, lembar kegiatan siswa, kunci jawaban, dan latihan soal untuk mengevaluasi sejauh mana kemampuan siswa dalam memahami materi yang telah disampaikan disertai kunci jawaban.

Penilaian selanjutnya yaitu oleh ahli bahasa yang terdiri dari aspek kelayakan bahasa sesuai dengan kaidah bahasa Indonesia. Penilaian ini dilakukan oleh Ibu Salati Asmahasanah M.Pd. Hasil yang diperoleh yaitu sebesar 75\% dengan kategori valid. Adapun masukkan yang 
diberikan yaitu meperbaiki kalimat pada tujuan pembelajaran "Melalui kegiatan berdiskusi siswa mampu menyebutkan syarat-syarat yang mempengaruhi kualitas air dengan benar" menjadi "Melalui kegiatan diskusi siswa dapat menyebutkan 3 syarat yang mempengaruhi kualitas air dengan benar" dan menambahkan kalimat pengantar pada kegiatan ayo mengaji serta mendeskripsikan kaitannya antara materi dengan ayat yang disajikan pada modul pembelajaran. Modul pembelajaran ini disusun dengan menyesuaikan pada kebutuhan siswa. Bahasa yang digunakan pun sederhana sehingga lebih mudah untuk memberikan pemahaman kepada siswa mengenai materi. Adapun pernyataan yang sesuai menurut Prastowo (2014 : 379) kalimat yang disajikan dalam modul harus singkat dan jelas, adanya petunjuk sehingga memudahkan ketika akan digunakan oleh guru dan siswa. Hal ini menyatakan bahwa bahasa sangat diperhatikan dalam penyusunan modul yang sesuai dengan kebutuhan siswa yaitu cukup jelas dan sederhana sesuai dengan perkembangan siswa. Maka dari itu modul pembelajaran ini layak untuk digunakan karena sesuai dengan kondisi siswa di lapangan.

Penilaian ahli desain dilakukan oleh Bapak Muhammad Fahri, S.S., M.Pd.I. Pada bagian desain diperoleh hasil sebesar 70,83\% dengan kategori valid. Ada beberapa masukan yang diberikan yaitu warna background pada modul pembelajaran terlalu gelap sehingga peneliti merubah warna background menjadi sedikit lebih terang. Selain menyesuaikan dengan kebutuhan siswa modul pembelajaran harus didesain dengan menarik sehingga siswa tidak mudah bosan hal ini didukung dengan pernyataan yang dijelaskan oleh Gita, dkk (2018 : 31) yang menjelaskan bahwa penyajian modul yang menarik akan memunculkan daya tarik siswa, dengan ketertarikannya tersebut maka menambah pengetahuan siswa dan menghilangkan rasa bosan pada saat kegiatan pembelajaran berlangsung. Tidak hanya dinilai oleh tim ahli modul pembelajaran juga dinilai oleh siswa melalui angket yang terdiri dari aspek ketertarikan, aspek materi dan aspek bahasa. Hasil yang diperoleh dari respon siswa yaitu sebesar 85,71\%. Modul harus menggambarkan kompetensi dasar yang akan dicapai oleh siswa, serta dirancang dengan menggunakan bahasa yang baik terutama lebih memperhatikan pada gaya bahasa sesuai dengan kondisi siswa yang ada, dan dilengkapi dengan ilustrasi atau gambar yang menarik dan sesuai dengan materi yang akan disampaikan (Arum dan Wahyudi, 2016 : 240).

Modul pembelajaran ini juga layak digunakan dan dapat mengembangkan rasa ingin tahu siswa, hal ini dapat dilihat dengan adanya perbedaan hasil rata-rata nilai posttest pada kelas eksperimen dan kelas kontrol yaitu sebesar 6,42857 dengan sig (2-tailed) sebesar 0,000. Dari hasil tersebut maka $\mathrm{H}_{\mathrm{a}}$ diterima dan terdapat perbedaan yang signifikan terhadap penggunaan modul pembelajaran ini. Peningkatan lebih besar pada kelas eksperimen, karena kelas eksperimen adalah kelas yang menggunakan modul pembelajaran IPA terintegrasi nilai agama untuk mengembangkan karakter rasa ingin tahu siswa. 


\section{SIMPULAN}

Berdasarkan dari hasil penelitian dapat diambil kesimpulan bahwa modul pembelajaran IPA ini layak digunakan. Hal ini dapat dibuktikan dengan persentase perolehan hasil kelayakan dari aspek materi yaitu sebesar 81,73\% dengan kategori valid, aspek bahasa diperoleh hasil sebesar 75\% dengan kategori valid, aspek desain diperoleh hasil sebesar 70,83\% dengan kategori valid dan hasil angket respon siswa sebesar $85,71 \%$. Selain penilaian dari tim ahli dan respon siswa, modul pembelajaran dapat mengembangkan karakter rasa ingin tahu siswa, karena adanya perbedaan peningkatan karakter rasa ingin tahu siswa pada kelas eksperimen dan kelas kontrol. Hal ini dapat dilihat dengan adanya perbedaan hasil rata-rata nilai posttest yaitu sebesar 6,42857 dengan dengan sig (2-tailed) sebesar 0,000. Dari hasil tersebut maka $\mathrm{H}_{\mathrm{a}}$ diterima dan terdapat perbedaan yang signifikan terhadap penggunaan modul pembelajaran ini. Maka dapat disimpulkan bahwa modul pembelajaran IPA terintgerasi nilai agama untuk mengembangkan karakter rasa ingin tahu layak digunakan.

\section{DAFTAR PUSTAKA}

Arum, Tya Sekar, dan Wahyudi.2016. Pengembangan Modul Pembelajaran Tematik Integratif Subtema Hubungan Makbluk Hidup Dalam Ekosistem Pendekatan Saintifik Untuk Kelas 5 SD. Jurnal Scholaria Vol. 6 No. 3. Hlm. 240.

Badan Standar Nasional Pendidikan. 2016. Instrumen dan Deskripsi Kegrafikaan SD. Jakarta : BSNP Indonesia.

Faizah, S.N. 2017. Pengembangan Modul IPA Berbasis Integrasi Islam dan Sains dengan Pendekatan Inkuiri di MI Salafiyah Kutukan Blora. Jurnal At-Thulab Vol 1. No.2. Hlm. 103.

Gita, S. D., dkk. 2018. Pengembangan Modul IPA Materi Hubungan Makbluk Hidup dan Lingkungannya Berbasis Pendekatan Kontekstual. LENSA (Lentera Sains) Jurnal Pendidikan IPA Vol. 8. No. 1. Hlm. 31.

Latifah, S. 2015. Pengembangan Modul Ipa Terpadu Terintegrasi Ayat-Ayat Al-Qur'an Pada Materi Air Sebagai Sumber Kehidupan. Jurnal Ilmiah Pendidikan Fisika Al-BiRuNi No. 04 Vol. 2. Hlm. 157.

Mulyasa. 2016. Pengembangan dan Implementasi Kurikulum 2013. Bandung : PT Remaja Rosdakarya.

Prastowo, A. 2014. Panduan Kreatif Membuat Bahan Ajar. Jogjakarta : Diva Press. 
Raharja, Steven, dkk. 2018. Mengukur Rasa Ingin Tabu Siswa (Measuring Students' Curiosity). A Journal of Language, Literature, Culture, and Education POLYGLOT Vol. 14, No. 2. Hlm. 153.

Riduwan. 2012. Skala Pengukuran Variabel-V ariabel Penelitian. Bandung : ALFABETA.

Sudjana, Nana, dan Ahmad Rivai. 2013. Teknologi Pengajaran. Bandung : Sinar Baru Algensindo.

Sukmadinata, N. S. 2011. Metode Penelitian Pendidikan. Bandung : PT Remaja Rosdakarya.

Suyadi. 2015. Strategi Pembelajaran Pendidikan Karakter. Bandung : PT Remaja Rosdakarya.

Trimantoto, A. S. 2016. Pengembangan Modul Pembelajaran Tematik Merawat Hewan dan Tumbuhan Tema 7 Untuk Siswa Kelas 2 SD. E-Jurnal Prodi Teknologi Pendidikan Vol. V No. 6. Hlm. 214-215.

Wena, M. 2016. Strategi Pembelajaran Inovatif Kontemporer. Jakarta : PT Bumi Aksara. 